\title{
Mangroves, mudbanks and seawalls: whose environmental knowledge counts when adapting to sea level rise in Suriname?
}

\author{
Ravic P. Nijbroek ${ }^{1}$ \\ Conservation International, USA
}

\begin{abstract}
Coastal communities in Suriname are highly vulnerable to sea level rise and will need to adapt. Global assessments of climate risk and vulnerability, such as IPCC reports, play an important role in the development of local adaptation policies. The aim of this article is to explore global and national discourses on climate change vulnerability and their local expressions in national policies. These discourses are juxtaposed with local understandings of vulnerability and adaptation possibilities. These different epistemologies are examined to understand how different knowledge claims and existing power structures lead to contested adaptation solutions. In Suriname, conflict arises in understandings of the coastal geomorphology and ecology of mangroves, and what role they play in adaptation to sea level rise. Conflicting environmental knowledges of mangrove ecology, species diversity, and their potential role in coastal erosion have led to conflict between the state and some local communities, resulting in potential maladaptations. New approaches for a 'situated environmental science' are explored to find more socially inclusive adaptation solutions.
\end{abstract}

Key words: Adaptation, sea level rise, mangrove, seawall, knowledge, Suriname

\begin{abstract}
Résumé
Les communautés côtières au Suriname sont très vulnérables à l'élévation du niveau de la mer et devront s'adapter. Les évaluations globales du risque climatique et de la vulnérabilité, tels que les rapports du IPCC, jouent un rôle important dans le développement des politiques d'adaptation locales. Le but de cet article est d'explorer les discours nationaux et mondiaux sur les changements climatiques et la vulnérabilité et leurs expressions locales dans les politiques nationales. Ces discours sont juxtaposés avec les conceptions locales de la vulnérabilité et des possibilités locales d'adaptation. Ils nous permettent de comprendre comment les différentes prétentions à la connaissance, et les structures de pouvoir existantes, conduisent à des solutions d'adaptation contestées. Au Suriname, le conflit se pose à propos de la connaissance de la géomorphologie côtière, et de comprendre le rôle des mangroves dans l'adaptation à l'élévation du niveau de la mer. Des connaissances conflictuelles de l'environnement a conduit à des conflits entre l'Etat et certaines communautés locales, ce qui conduit à la possibilité de mal-adaptation. Je explorer de nouvelles approches pour une «science de l'environnement situé» à trouver plus de solutions d'adaptation qui sont plus socialement inclusive.
\end{abstract}

Mots clés: adaptation, élévation du niveau marin, mangrove, la digue, la connaissance, le Suriname

\begin{abstract}
Gemeenschappen gelegen aan de kust van Suriname zijn zeer kwetsbaar voor de gevolgen van zeespiegel stijging en zullen aanpassingen moeten plegen. Wereldwijde evaluaties van de risicos en kwetsbaarheden van klimaatsverandering, zoals de IPCC rapporten, spelen een belangrijke rol in de ontwikkeling van lokale adaptatie plannen. Het doel van dit artikel is om te onderzoeken wat de invloed is van internationale en nationale discussies op nationaal beleid. De discussie kan dan worden vergeleken met de lokale visie van de kwetsbaarheid en adaptatie mogelijkheden i.v.m klimaatverandering. De verschillende standpunten worden bestudeerd om beter te begrijpen hoe verschillende theorieën en bestaande machtstrukturen kunnen leiden tot betwiste adaptatie modellen. Het verband tussen de rol van de kustelijke geomorphologie en mangrove ecologie, en zeespiegelstijging adaptatie is nog betwist in Suriname. Verschillende theorieën over mangrove ecologie en biodiversiteit, en hun mogelijke rol in kusterosie hebben geleid tot conflicten tussen de overheid en lokale gemeenschappen. Dit kan mogelijk leiden tot het aannemen van schadelijke i.p.v. behulpzame adaptaties. Er wordt gekeken naar een nieuwe 'situated environmental science' aanpak die mogelijk zal leiden tot sociaal veelomvattende adaptatie oplossingen.
\end{abstract}

Trefwoorden: Adaptatie, zeespiegelstijging, mangrove, zeedijk, kennis, Suriname

\footnotetext{
${ }^{1}$ Dr. R.P. Nijbroek, Senior Technical Director, Conservation International, Arlington, VA, 22202, USA. Email: rrravic "at" hotmail.com. I acknowledge a McKnight Doctoral Fellowship from the Florida Education Fund. I am especially thankful to farmers at Weg Naar Zee and the community leaders at Totness who participated in this research. I furthermore wish to thank two student assistants, Vanessa Kadosoe and Cindy Kasanpawiro, two student paper judges who gave helpful comments during the DOPE 2012 conference, and two anonymous reviewers.
} 


\section{Introduction}

Adaptation to the impacts of climate change has become a major concern for the governments of vulnerable nations. The Intergovernmental Panel on Climate Change (IPCC), the leading global scientific body responsible for providing scientific evidence and guidelines for policy makers, has made a strong case for adaptation to climate change (Nicholls et al. 2007). In five consecutive assessment reports, the emphasis has gradually shifted from mitigation to adaptation (IPCC 1990, 1995, 2001, 2007, 2014). Much emphasis is on the most vulnerable countries whose populations will bear the brunt of the impacts and are lagging behind in adaptive capacity (IPCC 2012; World Bank 2010). Coastal populations are especially vulnerable to climate risks (Nicholls et al. 2007). A global assessment of populations living in low-elevation coastal zones (LECZ), for example, ranks four Caribbean nations in the top ten in terms of the percent of their total population living in the LECZ: Bahamas (first), Suriname (second), Guyana (fifth), and Belize (eighth) (McGranahan et al. 2007). Similarly, a World Bank study of the impacts of sea level rise (SLR) on developing countries finds Suriname highly vulnerable (Dasgupta et al. 2007). The World Bank (2010) estimates that the global cost of adaptation will be in the range of US\$70 to 100 billion per year by 2020, but unfortunately very little is being invested in understanding adaptation options in the region. For example, of all ODA by OECD members, $15 \%$ is climate related aid, only one third of this is for adaptation, and just under $0.5 \%$ is for the Caribbean region (OECD 2013).

The focus of this study is on coastal communities in Suriname who are vulnerable to SLR, and where mangroves are expected to play a major role in providing adaptation solutions. Global assessments of climate risk and vulnerability, such as IPCC reports, play an important role in the development of national adaptation policies. The aim of this article is to explore global and national discourses on climate change vulnerability, in order to better understand how national and local climate change adaptation policies are informed by the scientific knowledge presented in these reports. This article furthermore explores the perceived risk identified by local actors who develop adaptation strategies based on local knowledge gathered over multiple generations, and retained through storytelling and other social practices. These different epistemologies, one influenced by positivist scientific explanation and the other by local understanding and practice, are juxtaposed in order to understand how different knowledge claims and existing power structures lead to contested adaptation solutions. This work supports what has been called "a situated environmental science" (Forsyth 2011) and aims to improve climate change adaptation policies to be more socially inclusive and open to multiple scientific explanations (Cook and Lane 2010).

\section{Background}

There is an abundance of scientific literature on climate change, asking important questions such as how to adapt to it (Agrawal 2010; Pelling 2011), how much it will cost (World Bank 2010), who should pay for it (Adger et al. 2006; Paavola and Adger 2002), and how species may be affected through complex ecological processes (Hannah 2010)? The global community has strongly condemned the lack of consensus by world leaders on tackling this issue that will seemingly leave no part of the earth unaffected, terrestrial or marine. At the local level, existing power structures often influence how global concerns are transformed into law, policy and action. These power structures determine how knowledge is filtered and reproduced, often to maintain the status quo. In this context, I place the struggle over how coastal communities in Suriname are able to adapt to climate change, specifically SLR, which is simultaneously a struggle over power/knowledge. ${ }^{2}$ This type of analysis is important because it not only sheds light on who the winners and losers are of a particular adaption policy but, more importantly, it asks how knowledge was constructed and who constructed it. In other words, which stakeholders were able to participate in the policy development process and which environmental knowledges were excluded? This requires an approach that situates global (universal) discourses locally, deconstructs local narratives, and critically examines both.

Political ecologists have long used narrative analysis to understand multiple and politicized meanings of environmental crises. Blaikie and Brookfield (1987) were early pioneers in the genre and questioned how scientific explanation of land degradation were constructed and for whose benefit. Fairhead and Leach (1996) analyzed narratives of 'deforestation' in Guinea and showed how false narratives of deforestation resulted in

\footnotetext{
${ }^{2}$ The inseparability of power/knowledge was explained by Michel's Foucault (1994), who showed how social groups, or members of social groups, structure others' outcomes trough the control over knowledge production.
} 
global actors incorrectly placing blame on local villagers. Through field research and historic aerial photographs, they found that local farming practices were instead increasing biomass and creating forested landscapes. Forsyth and Walker (2008) examined multiple narratives of deforestation and soil erosion in northern Thailand which placed blame or praise on the farming practices of marginalized upland communities. They showed that the politicized understandings of the roles that these communities were ascribed in lowland environmental crises were neither true nor false, and far more complex than any simple narrative could explain. Such studies challenge accepted environmental discourse by carefully examining multiple situated knowledges of environmental science. Others have since also argued that there is a need to carefully examine how politics influences scientific explanation in order to come to more useful understanding of environmental crises and produce more accurate environmental policies (Cook 2010; Forsyth 2003; Forsyth 2011).

Globally, the mangrove and climate change discourse focuses on the benefits that mangroves provide in reducing storm damage (Arkema et al. 2013; Costanza et al. 2008) in addition to the provision of habitat for marine and estuarine fauna, and resource use value such as production of timber and non-timber products (Barbier et al. 2011; Donato et al. 2011; McLeod and Salm 2006; Wells et al. 2006). This discourse around the roles that mangroves play in protecting coastlines from storms and erosion is a universally accepted explanation that warrants no questioning and requires no proof. As the discourse is applied to local circumstances, coastal erosion is immediately tied to loss of mangrove habitat, and in doing so, new narratives develop that assign blame to 'mangrove destroyers' who are invariably coastal communities living near mangrove habitat. These accused actors are subsequently made responsible for increasing vulnerability to SLR for all coastal inhabitants.

Discussions on adaptation to SLR often center on seawall construction versus mangrove rehabilitation, each providing different opportunities and losses for different communities. Global predictions of SLR are strongly informed by IPCC assessment reports which provide estimates of mean global sea levels in 2100. While the IPCC reports are updated every four to five years, each time based on improvements in modeling, they generally lack detail of the multiple ways in which SLR will impact coastal communities in the short term. With only long-term projection and limited local capacity to analyze actual sea level data and develop early warning systems, the conversation remains vague and local communities rely more heavily on past experiences of coastal flooding than future predictions. Through an analysis of positivist scientific publications and locally informed explanations of mangrove ecology and coastal erosion, it is possible to understand which uncertainties and assumptions are overlooked when developing new climate adaptation policies. This is important so that vulnerable communities are in fact not made more vulnerable through the implementation of poorly informed policies or maladaptations.

\section{Study sites}

Suriname is located in northeast South America and borders Guyana, French Guiana, Brazil and the Atlantic Ocean. It has a relatively small but ethnically diverse population of just over 500,000 people (ABS 2007). Throughout Dutch colonial rule, different people were either forcefully relocated to Suriname or voluntarily moved there, often tempted with multi-year contracts and the promise of a small piece of land. Thus, Suriname's ethnic heritage is formed by pre-Columbian inhabitants, African slaves, Europeans, and contract laborers from China, South Asia, and Indonesia (Java). More recently, Brazilian (mostly from northern states) and Chinese (working as contractors for road development projects and their families) are migrating to Suriname in the tens of thousands. Suriname became an independent nation in 1975 and experienced a period of military rule between 1980 and 1987. The ex-military dictator, Mr. Bouterse who is a popular and controversial figure, was elected president in 2010. The 2010 elections are mentioned here because the politics of the 2010 elections played an important part in the adaptation policy process as I shall explain later. After independence, military rule, and a period of structural adjustments in the 1990s, Suriname's economy stabilized in the 2000s and is now largely dependent on the exploitation of gold and oil reserves.

The research was conducted between 2009 and 2011 in three locations: the capital city Paramaribo (district Paramaribo), and the communities of Weg Naar Zee (district Wanica), and Totness (district Coronie). The districts Paramaribo and Wanica make up the greater urban area around Paramaribo where $67 \%$ of the total population lives (ABS 2007). Farmers at WNZ predominantly raise livestock and grow cash 
crops such as vegetables and flowers and the population is primarily of Indian and Indonesian descent. Totness is the administrative capital of the Coronie district and was first settled by Europeans in the late 1790s. Sixty percent of the district's population of 3,000, which is predominantly Creole, ${ }^{3}$ live on a narrow strip of land between the coastline in the north and the 3,500 $\mathrm{km}^{2}$ Coronie Swamp to the south. Coronie has the highest unemployment rate of any district in Suriname at 30\% (ABS 2007). The district is politically important because it has a disproportionately high representation in parliament with only $0.6 \%$ of the total population but $4 \%$ of parliamentary members.

Totness and WNZ were selected for this study because both places were experiencing coastal erosion and increased flooding at the time of this research, and the solutions that were being proposed, or implemented by the national government and local communities provide important insights into the adaptation policy creation process in Suriname. The government of Suriname has taken several steps to stop erosion and flooding in both locations. It completed an Integrated Coastal Zone Management (ICZM) project and WNZ was included as a pilot site (IaDB website, last accessed February 26, 2012). The government has furthermore started construction of a US\$70 million $14 \mathrm{~km}$ seawall in Coronie near Totness, and it completed construction of a 1 kilometer earthen dam enforced with logs and tarp at WNZ (see Figure 1).

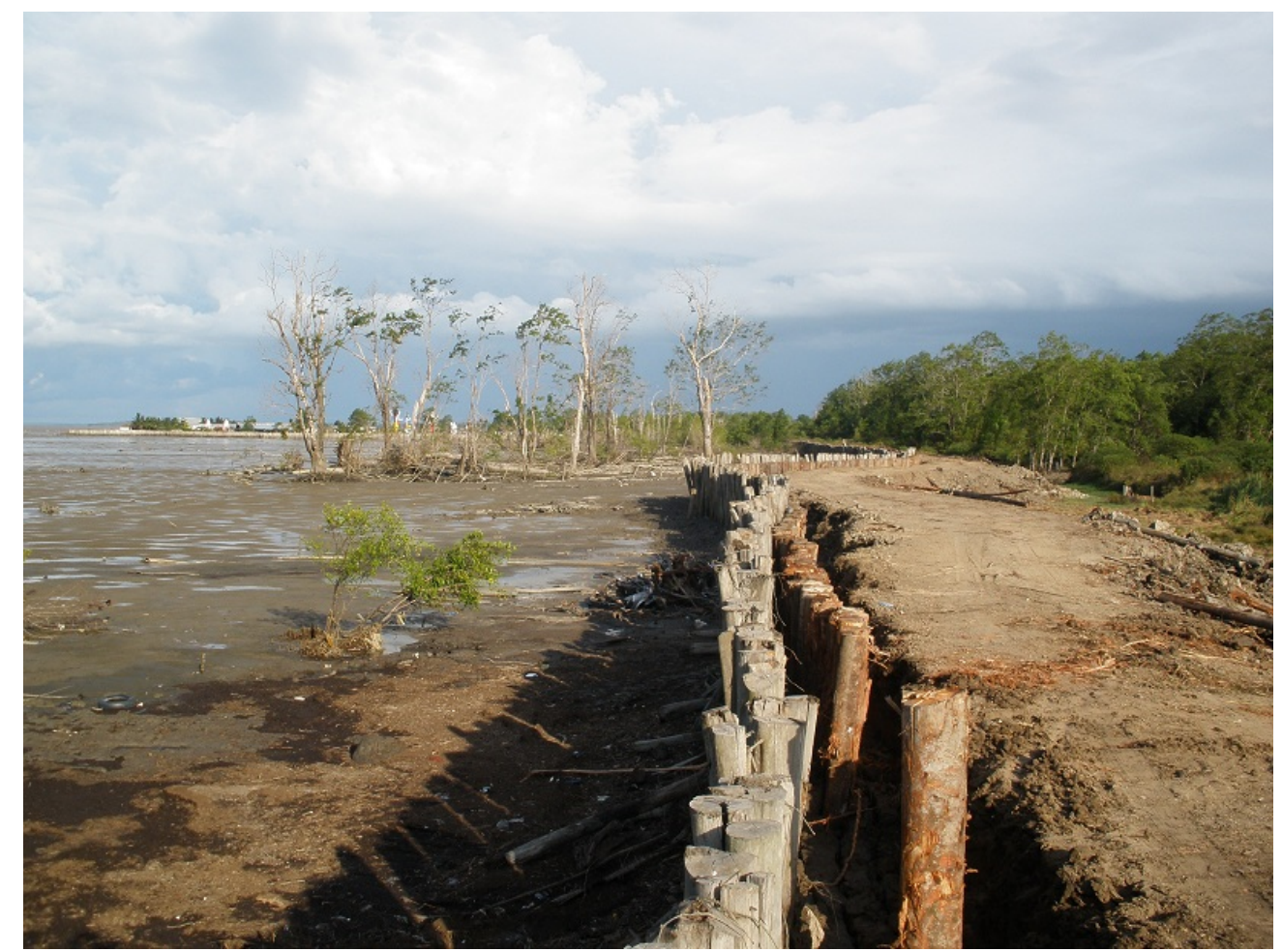

Figure 1: Re-enforcement of seawall at Weg Naar Zee. Photo taken at low tide. (photo: Ravic Nijbroek, September 2009).

\section{Methods}

As an exercise in situated environmental science, this study relies on mixed methods. As an environmental science study, it focuses on the available literature on mangrove ecology and geomorphology of the Suriname coast. I furthermore obtained gauge height data from the Maritime Authority of Suriname (MAS) to assess actual sea level rise. In addition, nine government officials from different ministries who served on an integrated coastal zone management inter-ministerial committee were interviewed in order to gain an understanding of environmental perspectives among policy makers. Finally, I interviewed three sluicegate managers, two fish smokers, and six additional experts (university professors, local consultants,

${ }^{3}$ Creoles and maroons are both descendants of Africans. A distinction is made between Creoles who live in urban areas and Maroons who live in traditional communities in the interior. 
etc.) with knowledge of the research topic. I relied much on archival research materials from government ministries, consultant reports, news sources and tourist brochures to broaden and supplement interview data.

I also collected anecdotal data on coastal farmers' local experiences of erosion and environmental change to strengthen the situated analysis. I conducted 20 semi-structured interviews among households at WNZ who live on the two roads located closest to the shoreline: Oedaraysingh Varmaweg and Brantimakaweg (WNZ refers to this location only and not the entire political territory). ${ }^{4}$ Residents were selected by visiting the area in the early evening hours when people usually have stopped farming and tend to relax outside before the mosquitoes arrive at sunset. After the first set of interviews, I used snowballing to be introduced to neighbors or family members. I conducted seven additional semi-structured interviews with key informants from Totness and people who were closely involved with the seawall project in Totness (i.e. representatives from the engineering firm who were contracted to construct the seawall). I chose to work with key informants in Totness instead of household representatives because several projects in recent years that focused on coastal erosion and water management had divided the community and the topic had become a sensitive issue to discuss publicly. The most contentious of these was the development of the seawall which divided the community in two camps, those in favor and those opposed. The interviews were supported with archival analysis of government reports and other historic documents. Combined, the biophysical and social data provided the information needed for a situated environmental science. Figure 2 shows the important features of the study sites.
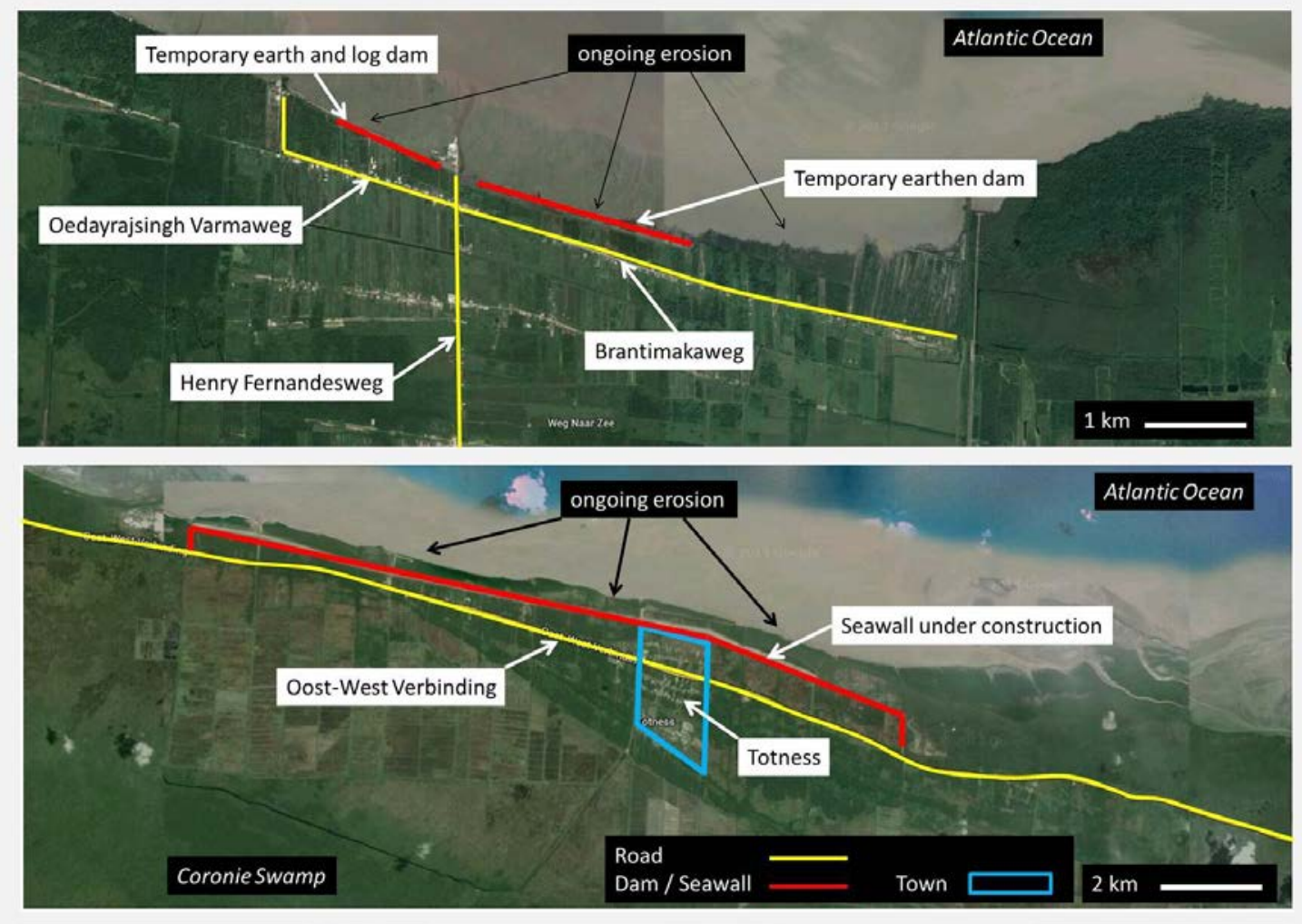

Figure 2: Important features of the study sites: Weg Naar Zee (top panel) and Totness (bottom panel). Background image: Google Maps.

The results are presented as three narratives that show how problematic assumptions of SLR and mangrove ecology become reified in local narratives. Environmental narratives are storylines or explanations of biophysical events that are generally accepted, yet may contain simplifications or errors. As Forsyth

\footnotetext{
${ }^{4}$ There are 67 permanent residences on the two roads nearest the shoreline at WNZ.
} 
explains, narratives frequently include concepts of blame assigned to different actors, as well as arguments that some urgent action must be taken by other, usually dominant, social groups (Forsyth 2011). These narratives can be found in the data (interviews, archival materials, etc.) by mapping key words, expressions and knowledge claims that are repeated by different groups. Prior to presenting these narratives, I include a description of the geomorphology of the Suriname coastline which helps to frame the remainder of the discussion.

\section{Geomorphology of the Suriname coastline}

The coastline of Suriname is roughly 400 kilometers in length, and is characterized by three prominent features. First, an inter-linked system of mangrove forests (predominantly Avicennia germinans or black mangroves) and mudbanks dominate the coastline and coastal geomorphology. There are also sandbanks that move in a similar fashion as the mudbanks, but these are not considered significant in this process. The mudbanks are formed by sediments that originate in the Amazon Basin, are first transported by the Amazon River and then the Guiana Stream before they are deposited to form banks that migrate north and west along the South American coastline. This system of mangroves and mudbanks is crucial to the narrative analysis that follows and will be explained in more detail below. Second, brackish and freshwater lagoons, locally called pannen, have developed immediately south of the mangrove belt, especially in the western part of the country where the coastline has a more northwesterly direction (Spaans 2003). These lagoons remain important areas for migratory birds, provide income opportunities from tourism, and are important sources of fish protein for coastal communities. The hydrology of these wetlands, as well as smaller creeks, is important for providing freshwater to the coast by creating a 'porous' semi-continuous flow where it has not been disturbed. Third, the low-lying (approximately one meter above spring tide) coast consists largely of clay soils but is also interspersed by east-west ridges of sand and shell deposits, remnants of historic beaches along the coast. These are two to three meters above sea level and have been important areas for human settlement and road infrastructure over the centuries (Noordam 2007). All the features described above are located in the geologic Young Coastal Plain which is approximately $20 \mathrm{~km}$ wide in the east and $50 \mathrm{~km}$ in the west, and was formed during the Holocene (Noordam 2007). The remaining major physiographic regions are the Old Coastal Plain (Pleistocene), Savanna Belt (Late Tertiary), and the Interior which is part of the Precambrian Guyana Shield (Noordam 2007).

\section{Mangrove 'destruction' at Totness and Weg Naar Zee}

Mangroves have been well documented as having the ability to reduce losses from coastal storms. Costanza et al. (2008), for example, have calculated that coastal wetlands, many dominated by mangroves, provide billions of dollars worth in protection from hurricanes in the United States alone. Others have started to question this apparent fact. Feagan et al. (2010), for example, reviewed the evidence base after the widespread destruction and loss of life caused by the Indian Ocean Tsunami and found there is more complexity than the presence of mangroves alone in reducing storm damage. Factors such as topography and distance from shore are highly significant. In the case of Suriname, the concern is not with coastal storms but with erosion from constant wave energy and SLR. Mangroves are known to trap sediments and build up the coastline as sea level rises (Alongi 2008). There is a wide variety of mangrove species, however, and their ability to protect against erosion depend much on the species and local conditions (Hogarth 2007).

When speaking with government officials, coastal erosion at the two study sites was identified as caused by the destruction of black mangroves, locally called parwa. At WNZ, the destruction was blamed on local farmers and fishermen while farmers alone were determined to be the "mangrove destroyers" at Totness. To some extent, government officials also focus on land developers in northern Paramaribo outside the study sites. During a coastal zone management workshop, a government consultant spoke of "large-scale destruction of mangrove forests" by coastal residents (Deltares workshop, Krasnapolski Hotel, April 2009). When asked why fishers would destroy mangroves, the most common answer from government officials was that they use the wood for smoking fish. As a representative from the Ministry of Environment explained "Men gebruikt het gewoon voor het ... barbacotten van vis, roken van vis doen ze ook, maar ze gebruiken het ook voor andere doeleinden, vooral de vissers ..." (People use it to ... barbacot the fish, to smoke the fish, but also for other things, especially the fishers...). To a lesser extent, officials said that fishers use mangrove 
trees as poles to attach their fishing nets. There is little doubt however that fishers are primarily responsible for mangrove loss, which is captured in the above statement that starts with the general "people" but ends with a specification: "fishers."

Fishers confirmed that they use parwa for smoking fish but that, in fact, they do not cut down trees because freshly cut wood is too wet and does not burn well. Instead, fishers prefer to collect dead trees in areas where mangrove driftwood piles up. Both fishers and scientists who I spoke to confirmed that in certain areas driftwood piles up, potentially providing coastal protection from wave energy. Fish smokers further explained that many have shifted to using swit bontji (Inga sp.) because this species is widely available in the coast even though it does not give the fish the desired brown color that parwa wood provides which instead is artificially added with soy sauce.

The destruction narrative also assumes that parwa logs are used as poles for attaching fishing nets. This has been disputed by local fishermen because alternative hardwood species from the Interior forest last longer, and are preferred. Parwa may occasionally be used for construction as a temporary replacement, but the wood is considered to be of poor quality. It is too soft and has to be replaced too frequently. Even if fishers collected only parwa for smoking fish and fishing poles, the number of fishers in Suriname is very small relative to the size of forests of Avicennia germinans and their growth rate. There are fewer than 100 fish smoking establishments operating in Suriname and the majority are all small-scale family-owned operations (Capricorn Projekt 2009). Moreover, local residents explained that parwa can mature in five to six years which corresponds to reports of parwa regeneration in French Guiana (Gratiot et al. 2008).

While there is no evidence of regular use of parwa by residents of Totness and WNZ today, respondents readily admitted that they removed parwa and other coastal vegetation in relatively large volumes in the past, but for quite different reasons than suggested by government officials. After the military regime took power in 1980, land reform was introduced. Land ownership became a possibility for many poor people if they could prove that they were actively farming land which lay fallow before they occupied it, regardless of who 'owned' the land. WNZ experienced a small land rush during this period with settlers squatted on unused land to gain legal tenure. The first settlers had already arrived in small numbers during the previous three decades, and experienced similar requirements. One respondent who settled at WNZ in the early 1960s explained that his family was required to put land into production in order to receive title for the land. This included draining the land by manually digging ditches and removing the vegetation. The government also encouraged farmers to plant rice in the 1970s. This is a recurring theme, as I describe below.

Large scale mangrove removal in Totness was carried out in the past to create polder plantations. The region was settled in the late $18^{\text {th }}$ century during a period when British settlers occupied the area (Van der Veen et al. 2010). Settlers were not only concerned with managing potential saltwater intrusion from high tide events, but also with the frequent flow of freshwater from the Coronie Swamp, which moved freely across the sand and shell ridges from the swamp in the south to the coast in the north during the wet season. The swamp has always been a hazard and a resource, because it causes flooding but also provides much needed fresh water and fish during the dry season. Optimal water management was thus achieved through a complex system of polders which was officially recognized by the Dutch Queen in 1917 (Van der Veen et al. 2010). Ongoing erosion in Totness does not appear to be related to specific mangrove removal events. This is because regular coastal erosion and accretion has been recorded along the Totness coast during the last 200 years. According to Wekker (1984, referenced in Augustinus and Teunissen 2004), coastal erosion was witnessed in Totness and nearby plantations during the following periods: 1810 to 1850, 1914 to 1950, and 1960 to 1980. These periods were always followed by phases of coastal accretion (Figure 3).

\section{Scientific and local knowledge of mangrove ecology}

Augustinus (1978; 1980; 2004), a physical geographer who has spent much of his career studying the coastal geomorphology of the Guiana coast, provides a scientific explanation of the role that mudbanks play in mangrove ecology. Fine silt and clay particles, originating in the Amazon River, are transported via the Guiana Stream along the northeast coast of South America where they interaction with northeast trade winds and create a system of migrating mudbanks that dampen wave energy, thus protecting coastal mangroves (Allison et al. 2000; Augustinus 2004). Sediments accumulate on the front (west) end of the mudbank and mangroves colonize it when the elevation is high enough with respect to mean high water, where the trees continue to trap sediments (Augustinus and Teunissen 2008). As mudbanks move west at a rate of 
approximately $1.5 \mathrm{~km}$ per year, mature mangrove forests become exposed to undampened waves and collapse (Augustinus 2004). Mudbanks therefore provide primary protection from erosion, while mangroves provide secondary protection because they alone cannot withstand the force of wave energy. Mangrove forests without accompanying mudbanks slowly die off resulting in coastal erosion, and these are locally referred to as mangrove kerkhoven (mangrove graveyards). This is an important deviation of the general scientific explanation of the primary (as opposed to secondary) role of mangroves in coastal protection.

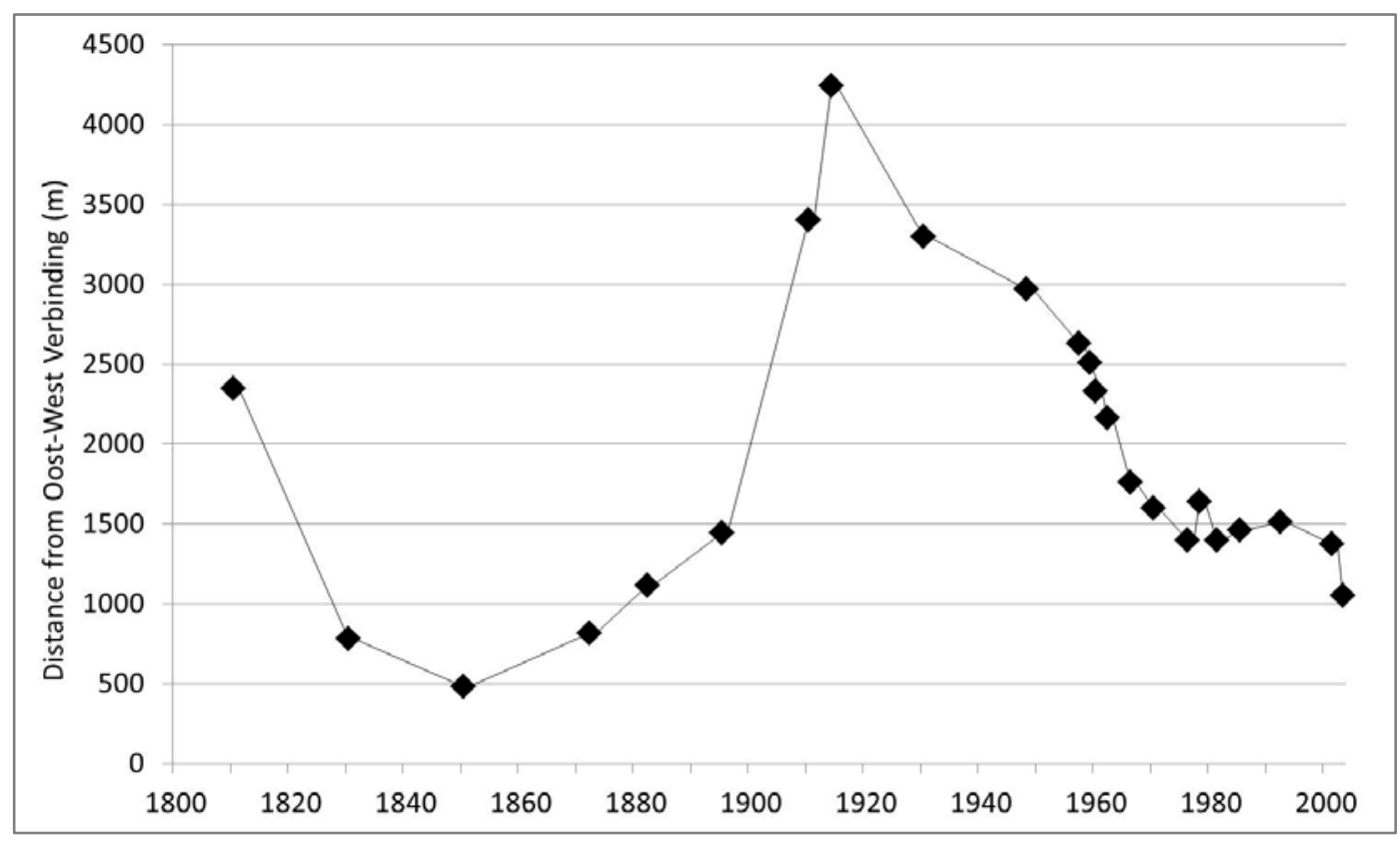

Figure 3: Erosion and accretion of shoreline near Totness, Coronie, from 1810 to 2003, relative to a fixed road called Oost-West Verbinding (modified from Augustinus and Teunissen 2004).

Any particular location on the coast may be experiencing land accretion or erosion, in a process that repeats itself about every 30 years (Augustinus 2004) (see Figures 4a and 4b). At the meso scale of several decades, the shoreline is highly variable and can switch relatively suddenly (within a few years) from an eroding to a accreting shoreline depending on the presence or absence of mudbanks. At the macro scale of decades to centuries, however, the Suriname coast has been found to have a net accretion rate (Augustinus 2004). The 30 year periodicity may change if the northeast trade winds also change direction, which would result in modifications to the general shape of mudbanks (Berrenstein 2010).

While technological advancements, such as time series aerial photography, have been invaluable for developing scientific knowledge of coastal geomorphology, local communities have additional knowledge of coastal processes. Mr. Alex Feller is a farmer at plantation Mary's Hope near Totness and chair of the local Committee for the Rehabilitation of the Northern Coronie Polder. He has been an outspoken critic of the government's poor water management in the district as well as the new seawall being constructed. ${ }^{5} \mathrm{Mr}$. Feller explains that locals are aware of two processes that impact mangrove growth: active and passive growth phases. Active growth occurs when the presence of a mudbank protects mangroves. Passive growth, however, is driven by periods when large quantities of freshwater flow from the Coronie Swamp north and "calms" the coastal waters and waves. This process involves the stratification of fresh and salt water and is referred to by community elders as "the meeting of the waters."

\footnotetext{
${ }^{5}$ Mr. Feller, as an activist, has requested specifically that I use his name in this article rather than remain anonymous.
} 


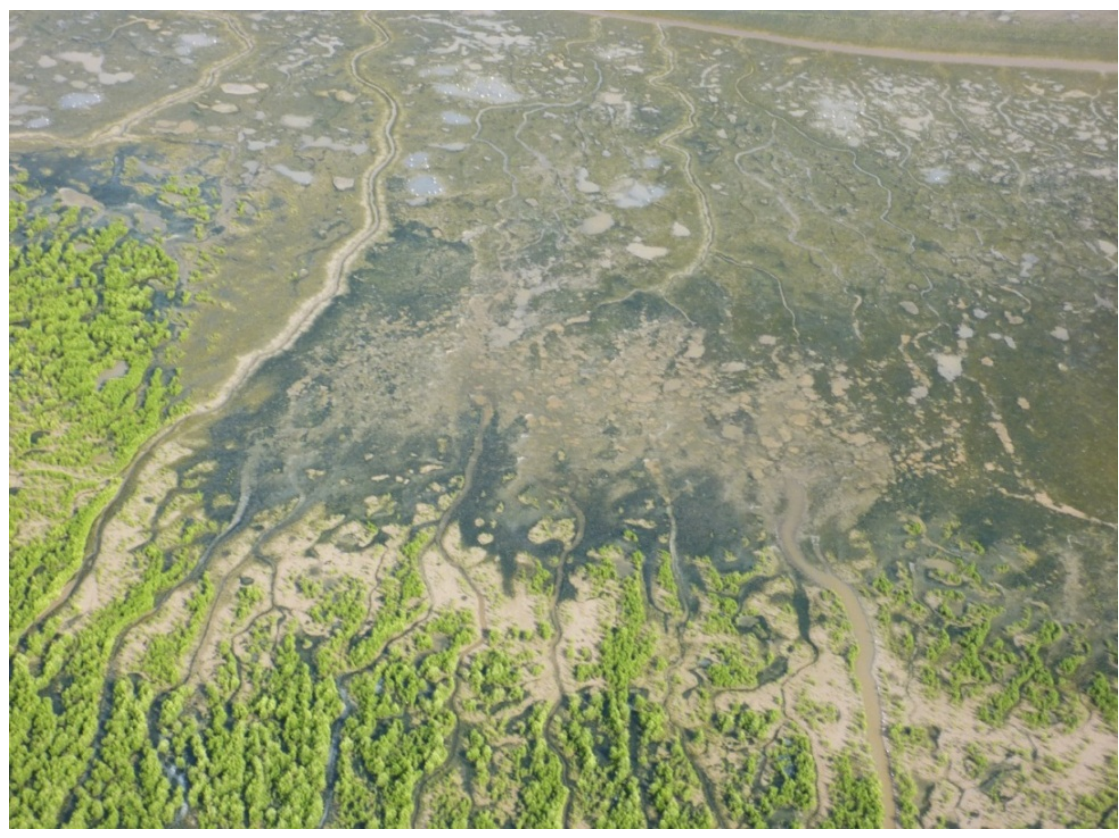

Figure 4a: Young black mangroves (Avicennia germinans) growing along the coast with presence and protection of a mudbank. Note also the many smaller creeks and streams. This photo was taken in October 2010 west of Weg Naar Zee (photo: D. Hoekman).

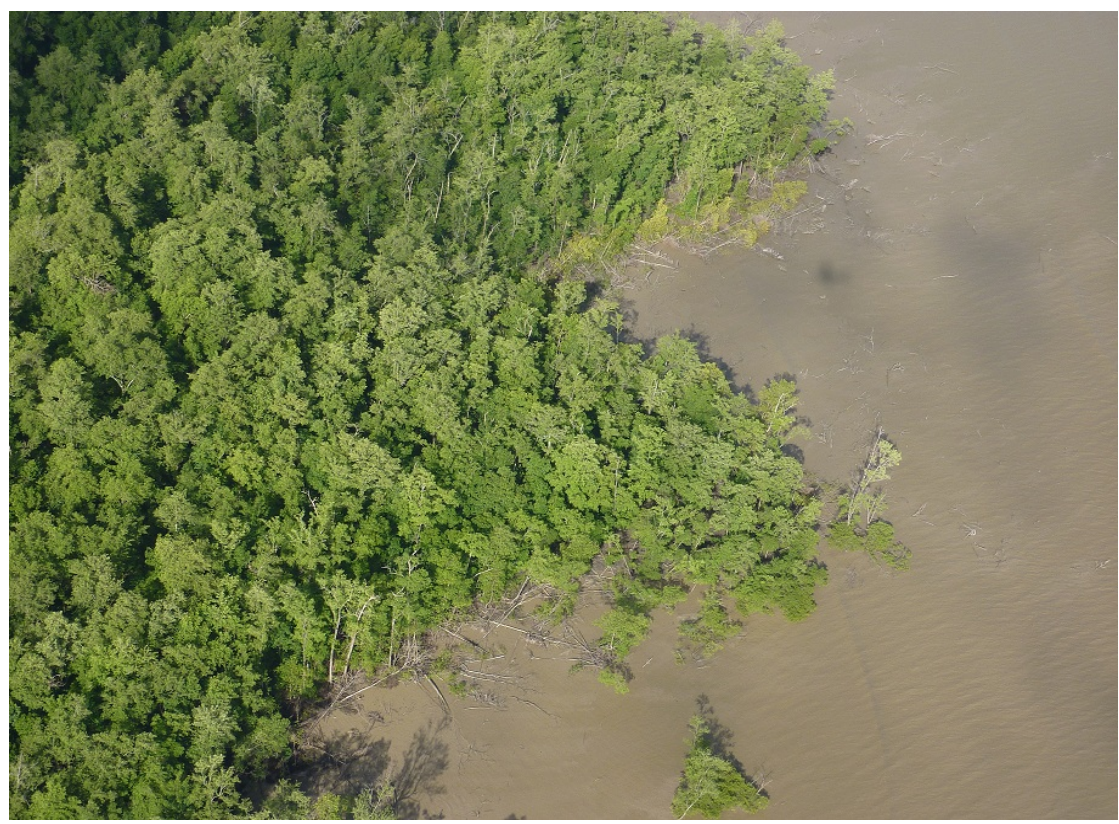

Figure 4b: Mature mangrove collapse and coastal erosion in the absence of a mudbank. This photo was taken in October 2010 east of Totness (photo: D. Hoekman).

The free flow of freshwater has been obstructed by various infrastructure projects during the last 50 years and Mr. Feller's committee is trying to restore this flow. After the main road, the Oost-West Verbinding (East-West Connection), was completed in the late 1960s, the district of Coronie was connected with Paramaribo by land, and several large-scale development projects were implemented in Coronie. The Prosperity Fund (Welvaartfonds) was used to start a new coconut polder near the eroding coast (Schalkwijk 
2009). This polder was equipped with a new pumping station and seawall, but the project quickly failed as a result of continued erosion. The Tien Jaren Plan (Ten Year Development Plan) expanded the Oost-West Verbinding further west and large-scale mechanized rice farms were introduced in Coronie (Schalkwijk 2009). Multiple small dams were constructed to block the flow of freshwater from the Coronie Swamp in order to protect the rice plantations. Members of the Committee for the Rehabilitation of the Northern Coronie Polder believe that successive government projects, starting with the construction of the Oost-West Verbinding, limited freshwater flow to the coast and that the disruption of passive growth is a significant contributing factor in mangrove die-off and subsequent coastal erosion. As one informant explained:

Het is algemeen bekend. Iedereen in Coronie kan je dit verhaal vertellen, want zo hebben ze altijd geleefd. Dat het water altijd doorstroomde naar zee, en dan hadden ze ook altijd genoeg vis" (It is common knowledge. Everybody in Coronie can tell you this story because this is how they have always lived. The water always flowed to the ocean and then there was also plenty of fish). (Interview, March 2010)

The Committee's main campaign carries the slogan "Let the Waters Flow" but it has had limited success so far.

Scientists who I interviewed agree that freshwater plays an important factor for the creation of optimal salinity conditions for mangrove growth of certain species. In addition to parwa, two other mangrove species are found in abundance in Suriname: Rhizophora mangle or Red Mangrove (local name: mangro) and Laguncularia racemosa or White Mangrove (local name: akira). Parwas, or black mangroves, are most salt tolerant, followed by red and then white mangroves (Hogarth 2007). The distribution of these species along rivers and creeks reflects this tolerance gradient (Augustinus and Teunissen 2004). Parwas grow nearest to the shore but still require freshwater for optimal conditions, and could die if salt concentrations are too high. Large scale parwa die-offs have been recorded in areas where very high tide events allowed seawater to flow over elevated mangrove shorelines and created shallow saltwater lagoons. High salinity conditions are created in these lagoons due to evaporation, and in combination with drowning of parwa roots, trees do not survive (Augustinus and Teunissen 2004). There is no scientific or published evidence that the lack of flow from the Coronie Swamp to the coast has influenced the more recent loss of parwa, which has resulted in continued attacks on local knowledge claims which include explanations of the passive growth phase.

\section{Scientific understandings and local experiences of SLR}

Discourses of rising sea levels at the global scale can be confusing when trying to interpret the impacts locally. Global SLR predictions (in 2090-2099 relative to 1980-1999) by the IPCC have changed over time as follows: 13 to $94 \mathrm{~cm}$ (IPCC 1995); 9 to $88 \mathrm{~cm}$ (IPCC 2001); and 18 to $59 \mathrm{~cm}$ (IPCC 2007). The latest Assessment Report (IPCC 2014) shows a range of 26 to $82 \mathrm{~cm}$ for the mean global sea level rise for 2081-2100 relative to 1986-2005. For the worst case scenario (Representative Concentration Pathway 8.5), the rise by the year 2100 increases to $52-98 \mathrm{~cm}$. The maximum predicted SLR as published in these reports thus decreases and then increases while the reference and prediction periods also change. Local vulnerability studies, such as the Netherlands Climate Assistance Program Phase 2, focus on the worst case scenario only, which makes intuitive sense for risk management. More recent studies (BASC 2010; Delta Commissie 2008) indicate that the IPCC figures could be too low and that SLR in 2100 will be in the range of 1 to 2 meters. Such figures are confusing and can be misleading for local decision makers. What are local decision makers to do with predictions for the year 2100 when expectations of SLR in the next decade remain unknown? Furthermore, how exactly are coastal populations sensitive and vulnerable to SLR?

Sea Level Rise is experienced at different frequencies and in different ways by different actors. The main concern for coastal farmers with respect to SLR is high tide events, which salinize agricultural land and make it unproductive. Different forcing factors determine local tides and these can be predicted with relative accuracy for several years (although they do not include the additional rise in sea levels from climate change). Coastal Suriname experiences very high tides once or twice a year, which result in flooding in rural and urban areas. Sluicegate managers also show concern for high tide events which have overtopped sluice gates in Paramaribo in 2010. However, they are more concerned with higher than expected low tides that 
prevents them from draining excess water by gravity, which is a part of their daily responsibilities. It is therefore expected that one adaptation the government of Suriname will have to invest in is to modify all sluice gates while also equipping them with pumps to operate during low tide events.

In order to better understand the trend in SLR, I acquired additional gage height data from the Maritime Authority of Suriname (MAS) where they are primarily used for boat navigation. These data are based on water elevation at the mouth of the Suriname River collected every 15 minutes with an accuracy of 1 centimeter (A. Amatali, personal communication, December 23, 2012). The MAS corrected erroneous data and removed questionable measurements resulting in multiple data gaps. No data were available from 2000 to 2004 and several years have data that are less than 95\% complete: $1999-57 \%$; $2006-42 \%$; $2008-91 \%$; and $2009-35 \%$. The data nevertheless provide sufficient information for understanding basic trends (see Figure 5).

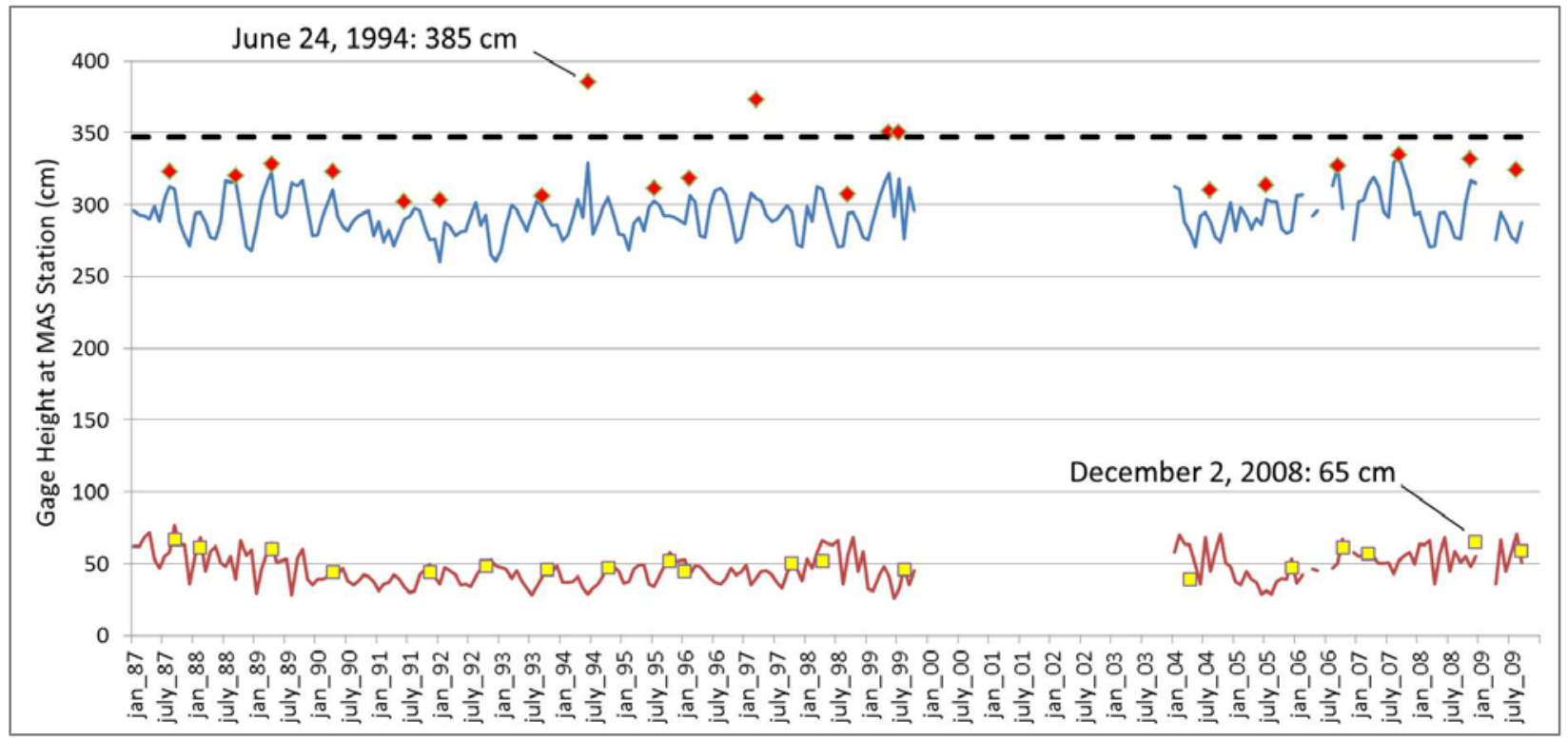

Figure 5: Maximum monthly high (blue line - top) and minimum monthly low (red line bottom) tide levels at the Maritime Authority of Suriname (MAS) gage station located at the mouth of the Suriname River. The highest high tide (red dots) and the highest low tide (yellow dots) events are important. The dotted line resembles the 50 year flood mark for greater Paramaribo.

Data processing involved several steps. First the twice daily high and low levels were identified. Next, the maximum monthly values of the mean daily high tide measurements (blue line) and the once a year maximum high tide measurements (red dots) were calculated. For example, the highest mean daily value for the month of January 1987 was $296 \mathrm{~cm}$ based on the two high tide readings on January 31 (272 and $307 \mathrm{~cm}$ ). However, the highest daily tide for all of 1987 was reached on August 11 at $323 \mathrm{~cm}$. Similarly, minimum monthly values of the mean daily low tides were calculated and plotted (pink line). In order to find out when drainage by gravity would have been most challenging (i.e. when low tide levels are still too high to open sluice gates), I focused on the minimum monthly low tide values (selected from two low tides events except for days when there was just one low tide). The highest of these 12 values was then recorded for each year. For example, the highest of the monthly lowest tides in 2008 was $65 \mathrm{~cm}$ reached on December 2. As the lowest low tides continue to rise, adaptation costs will also rise in places like Paramaribo to remove excess water from where it is not wanted. ${ }^{6}$

\footnotetext{
${ }^{6}$ While doing research, an extreme high tide event occurred on March 29, 2009, and many farmers' fields at WNZ were flooded with seawater. River water also flowed freely into Paramaribo and probably crossed the 50 year flood mark for the city (dotted line) but these data were not available from the MAS at the time of this writing.
} 
While high frequency and high magnitude events receive much attention in the discourse on climate impacts, there are equally important low frequency and low magnitude oscillations that ought to be considered. The Atlantic Multi-decadal Oscillation (AMO) is an apparent 65-80 year cycle during which temperatures in the Atlantic fluctuate by 0.4 degrees C (Kerr 2000; Gray et al. 2004). The AMO appears to have started a new warm phase in 1995 which will likely impact regional climate conditions. On the other hand, Gatriot et al. (2008) reported that an 18.6 year cycle, determined by the distance between earth and the moon, results in a mean high water (MHW) fluctuation of $12 \mathrm{~cm}$ along the northeast coast of South America. Moreover, they found that this oscillation in MHW is positively correlated with mangrove loss (erosion) and gain (land accretion), including up to 2 kilometers loss during one cycle peak period and a 3 kilometers gain of mangrove forest during a cycle low phase. The researchers also found that mudbank presence was insignificant for erosion and accretion due to the lunar cycle. This is yet another form of environmental knowledge based on satellite data of coastal areas in French Guiana that are uninhabited. The finding that mudbank presence was insignificant is a clear indication that additional research should be conducted to continue to improve our understanding of the different environmental knowledges. Time is a limited resource however, and the livelihoods of coastal communities continue to be at risk as sea levels rise. Are there not sufficient, and diverse, environmental knowledges to develop more inclusive policies without a better understanding of the lunar cycle impact?

\section{Discussion}

Political ecology's poststructural turn in the 1990s established discourse analysis as a component of political ecology research (Escobar 1996). The interconnectedness of discourse, knowledge and power established by philosophers like Michel Foucault means that in political ecology research "there cannot be a materialist analysis which is not, at the same time, a discursive analysis" (Escobar 1996: 46). Combined materialist and discursive political ecology research remains urgent in less developed countries of the Global South, especially in the face of climate change where many winners and losers will emerge from uneven adaptation policies. What Forsyth (2011) thus calls a "situated environmental science" also echoes calls for more ecological analysis (Walker 2005) as well as critical engagement with policy-makers in political ecology (Walker 2006).

Global discourses of mangrove function should be treated with caution when they are scaled down to local conditions and presented as scientific evidence. Local mangrove awareness campaigns, for example, often feature images of red mangroves (mangro) which have stilt roots but are far less abundant along the coast in Suriname. Black mangroves (parwa), which do not have stilt roots and are actually quite vulnerable to wave energy, are often misrepresented. The same awareness materials may include images of black mangroves that have succumbed to wave energy, a natural process, but with warning messages that people, presumably coastal fishers, are responsible for the destruction of coastal mangroves (Figure 6). While doing field research in Suriname, I participated in several coastal management workshops where speakers would argue that mangrove removal should be made illegal and "mangrove destroyers" prosecuted. They argued that current legislation which protects riparian vegetation, locally known as schermbos (protective forest), could be strengthened to include mangrove forests. These speakers were scientists or government officials, but never coastal residents.

Residents at WNZ expressed awareness of the concept schermbos which by law is defined as a strip of land 500 meters wide on either side of rivers, or 200 meters near creeks, that is legally protected and may not be removed (Ministerial order S.B 2005 no. 16). Many policy makers advocate for inclusion of mangroves in schermbos which would criminalize parwa removal without consideration of local circumstances or proper investigation. All scientific and local evidence points to parwa growth rates that are high enough so that mangrove harvesting could be done in a sustainable way. Residents at WNZ explained that parwas reach maturity within two to six years. Gratiot et al. (2008: 3) also report that parwa "communities can be wiped extensively during interbank phases, but can reappear in the same proportions within a period of two years" in French Guiana. The removal of mangroves would unnecessarily be criminalized if they were harvested at sustainable rates. The exact meaning of sustainable use would still need to be studied, and would likely consider other ecological benefits of mangrove forests, and adaptive management plans should reflect a "situated environmental science" (Forsyth 2011). 


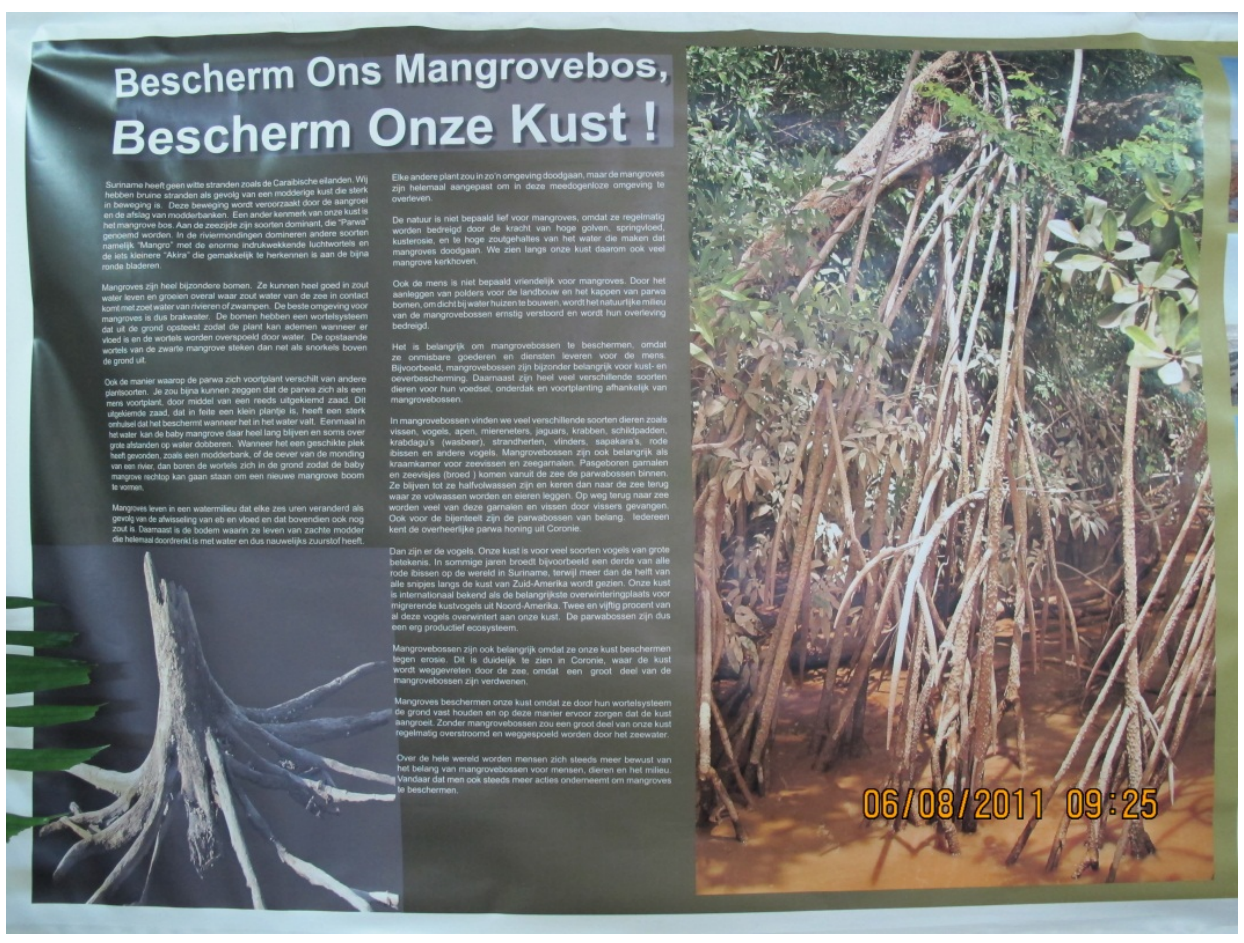

Figure 6: Part of a mangrove awareness poster which reads: Protect our mangrove forest, Protect our coastline! The mangrove species in the image on the right are red mangroves, however, which are not common along the coast at the intersection of mangrove and mudbanks but rather grow further south in the estuarine zone. The species on the left appears to be a dead black mangrove tree stump which is typical of areas where mudbanks are absent and black mangroves collapse (photo: R. Nijbroek).

Given the limitations of local and scientific knowledge (Agrawal 1995), a combined knowledge is often required for developing locally sustainable climate change policies (Batterbury et al. 1997; Mercer et al. 2010). Scientific knowledge has many advantages especially when trying to understand biophysical processes at broad spatial and temporal scales. The benefit of remote sensing for understanding coastal processes, for example, has been unmistakable even when it cannot explain social understandings of nature and how these are embedded in dominant discourses (Castree and Braun 2001). Neither can a positivist understanding of coastal dynamics capture the richly textured explanations of local communities with respect to local ecological processes which often grew out of historical narratives developed prior to the arrival of some of these technologies. But local knowledge has its limitations too. Ecological processes of timescales longer than one or more generations take time to be absorbed into local narratives, and some places have only been settled relatively recently. Respondents from Totness, for example, gave much more detailed explanations of coastal processes than those at WNZ where among all households interviewed, no one mentioned the word "mudbank" when asked to explain coastal processes.

Scientific literature on the impacts of SLR on mangroves remains inconclusive for Suriname. McLeod and Salm (2006) have indicated that mangroves will migrate landward with rising sea levels where conditions permit. Parkinson et al. (1994) analyzed the impacts of sea level rise on parwa systems in the Caribbean during the early Holocene, when it was even quicker than what scientists expect future SLR to be, and they found that mangroves would not need to migrate landward as long as the supply of sediments remains uninterrupted. Other evidence shows that both processes, landward migration and sediment accumulation, have taken place in the Caribbean for centuries (Alongi 2008) but it is not clear how parwas in Suriname behaved. It is probably safe to assume that the supply of sediments from the Amazon basin will not become a limiting factor in the near future. The Amazon produces several million tons per day (Allison et al. 2000) of which less than $10 \%$ is stored in migrating mudbanks (Augustinus 2004). In fact, Alongi (2008) has 
ranked the mangrove systems in northern South America as being the least vulnerable to the impacts of climate change.

Clearly, there are also anthropogenic influences that have disrupted the cycle of erosion and accretion at WNZ. Road construction and multiple dams blocking the flow of freshwater from the Coronie Swamp to the coast may have resulted in continuous erosion from 1914 until now (with a brief reversal around 1978). Around 1850, the coast at Totness eroded further than the current mark (Figure 3). Mr. Feller explained that the ocean came within $500 \mathrm{~m}$ of the main road although his dates vary somewhat from the data that Augustinus and Teunissen (2008) presented. According to Mr. Feller, Chinese laborers who arrived around 1850 were involved in clearing the polder canals, and this was a critical factor that restored the flow of freshwater to the coast which eventually resulted in a reversal of coastal erosion and started a process of accretion. Whether it was this activity, the arrival of a mudbank, a shift in the distance between the moon and earth, or a combination of all three (and perhaps other factors) remains unknown but the coast in Totness grew by almost $4 \mathrm{~km}$ in several decades after the canals were cleared.

Historical analysis of coastal erosion and accretion at Totness raises the question: why local residents were more proactive in water management in the mid $19^{\text {th }}$ century than a hundred years later, when they were faced with a similar challenge? Totness was transformed during this time from an isolated but self-reliant community to one that was increasingly connected to national politics and the global economy. After WWII, Suriname gained increasing independence from The Netherlands, and through the United States-initiated Marshall Plan for economic recovery of Europe, Suriname (as a Dutch colony) received its first big development aid package in 1948. The Welvaartsfonds (Development Fund) was used to invest in large scale agricultural projects in Totness, including the new Coconut polder which was located near the shoreline around 1959. Given that there had been continuous erosion for nearly 40 years, this seems like an odd choice, but according to Wekker (1984) there may have been some coastal accretion between 1950 and 1960. The post war period was also a time of optimism and trust in human ingenuity and engineering prowess. The new polder was equipped with state-of-the-art pumps which unfortunately all disappeared into the ocean when the tide turned and coastal erosion resumed.

The next phase of development funds was used to connect Totness with Paramaribo via the Oost-West Verbinding and mechanized rice farming was introduced in Coronie and Nickerie. Families in Totness, who previously planted rice for consumption and maintained diversified farms with fruit trees, vegetables, pigs and chickens, gradually abandoned these livelihoods and started practicing mechanized rice farming. Cheap loans were made available by the national Agricultural Bank to purchase equipment and take part in the Green Revolution. Many residents regret these choices now and one respondent expressed this accordingly:

Ieder erf had een combine, nieuwe machines. De Coroniaan heeft toen geld gezien als water, maar men is er niet goed mee omgegaan. De voorlichting was er niet (Every yard had a combine, all new machines. The Coroniaan saw money like it was water, but they did not spend it wisely. [Financial management] information was not provided.) (Respondent Interview, March 2010).

This post war period saw many political changes as well. The Staten van Suriname, a precursor of the national parliament, was formed in 1949. Totness, which had largely been independent, became increasingly part of the national political process for which it was not prepared. A local government official explained the following:

Ik denk dat [de politiek] een hele grote rol heeft gespeeld. Tijdens deze tijd, verkiezingen, krijg je stapels van solicitatie brieven van mensen die in dienst willen komen van de overheid zodat ze dan voor je stemmen ... Na de onafhankelijkheid is dat echt begonnen. (I think that [politics] played an important role. During this time, election time, we receive stacks of letters from people who want to be employed by the government in exchange for their vote.

This really started after independence). According to the high-ranking government official who I interviewed, Coronie currently has a disproportionate number of people receiving an official salary from the 
government but who are not actively performing work as a result of this system of essentially buying votes. This same official strongly believed that the political elite in Paramaribo prefer to maintain this status quo because the cost is low while the pay-off is high.

The latest attempt for political maneuvering in Coronie appears to be the US\$70 million seawall that is currently under construction. The seawall's primary stated purpose is to stop the ongoing coastal erosion. A high ranking government official with the Ministry of Planning and Development Cooperation (previously in charge of the execution of the seawall construction) denied that this was in any way political and expressed urgency for the protection of the community in Totness and the important Oost-West Verbinding which connects Paramaribo to the economically and politically important westerly district of Nickerie. Opinions differ, however, as can be seen from the answer given by an engineer who works on the project. When asked about the relatively high cost of this 14 kilometer seawall, he explained:

... every engineering object built has an economic justification, but not in Suriname. Here we build them because they are politically interesting ... If you don't build this seawall, then Bouterse will win the presidential elections and the country will be plundered anyway. The economic damage that the country will encounter from [current and former members, or supporters, of Mr. Bouterse's regimes] will be 100 times greater than the [cost of the] seawall. (Interview, October 2009).

As a result of decades of social and economic decay in Totness, it is unfortunate that the local residents lack the necessary skills to find employment with the Dutch engineering company that is building the seawall. While Totness may figuratively be saved from drowning in rising sea levels, it continues to drown in poverty and high unemployment (ABS 2007). Meanwhile, the cost of maintenance of the seawall has not been budgeted by the government even though maintenance cost of a similar, but much longer, seawall in neighboring Guyana is equivalent to $10 \%$ of its GDP (D. Singh, personal communication, February 21, 2012). The government also failed to study the impact of this seawall on coastal ecology elsewhere along the coastline. If this seawall alters the behavior of mudbanks further west, this will become disastrous for the economy of Nickerie where additional seawalls may need to be constructed in the future. One scenario put forth by several experts that I interviewed is that the approaching mudbank in Coronie may cause a shift, and enhance mangrove growth north of the seawall which may result in the seawall becoming physically located several kilometers from the coastline behind a mangrove forest. This project would then be categorized as a maladaptation, and a costly one at that.

\section{Conclusions}

This research project analyzed scientific and local knowledge of coastal biophysical processes, environmental histories, and past political projects to gain an understanding of possible adaptations to future SLR in Suriname. Global discourses of SLR and mangrove function are often presented locally with absolute certainty as matters of truth. However, there are important uncertainties and assumptions that appear to have been overlooked, potentially causing ill-advised adaptations to take place. For example, a focus on IPCC predictions of SLR in the year 2100 means that the immediate and local ways in which rising sea levels are experienced are ignored. Annual or bi-annual high tide water events that cause flooding and salinization of agricultural lands, and rising low tides which prevent drainage of excess water by gravity, should receive more attention from local policy makers. The steady increase of extreme events stress coastal communities by overwhelming and gradually breaking down coping abilities (Pelling 2011). Concern for long term gradual SLR increase is perhaps better suited for areas that experience minimal daily tidal influence, whereas the immediate focus along coastlines like Suriname's, where tides fluctuate about 2.5 meters, should be on high tide events that will gradually increase as sea levels rise.

While mangroves are known to provide protection from storm surges and limit coastal erosion (Alongi 2008), they behave differently in Suriname. Presence of mudbanks is essential for the growth of mangroves along the Suriname coast. Where mudbanks are absent, wave energy erodes the coastline and mangroves succumb to physical processes. False narratives of mangrove destruction are produced by government officials and reproduced in public fora. False claims are made that mangrove destruction is not a natural 
process but due to the actions of unknowing fisherfolk who cause the 'destruction.' Awareness campaigns also target such activities, but incorrectly show images of different mangrove species to support these narratives. A combined local and scientific knowledge is necessary to understand coastal processes and adaptation options to future SLR. In addition, research based on combined knowledge is still needed, and a more situated environmental science would be more inclusive of different environmental explanations and knowledges.

There is still much to be learned about sustainable adaptation solutions. It is clear, however, that adaptation interventions should never focus only on future biophysical vulnerability while ignoring preexisting socioeconomic vulnerabilities (Ribot 2010). Similarly, SLR impacts should not be studied in isolation but in combination with other biophysical and social processes such as changing wind patterns or political election cycles. Given the abundance of mangroves along the coast, the most important adaptation, I believe, is to allow the natural process of sediment accumulation and migration, as well as erosion and accretion, to take place unhindered where possible. If coastal populations and the government can learn from and adapt to the cyclical and dynamic nature of coastal processes, much time can be gained and scarce resources can be used elsewhere. This sentiment is perhaps best expressed by Mr. Feller who said:

With this seawall you cannot solve the problem ... [Instead] as the sea level rises, so the coast will rise. Later on, you will have to take care of water drainage. Only then will you have to decide: do I stay or do I move, but that is a long term issue ... that decision will have to be made in 50 or 60 years and that gives you the time to adapt (Feller, A. personal communication, October 3, 2009).

\section{References}

Agrawal, A. 1995. Dismantling the divide between indigenous and scientific knowledge. Development and Change 26: 413-439.

Agrawal, A. 2010. Local institutions and adaptation to climate change. In R. Mearns and A. Norton (eds.) Social dimension of climate change. Washington, DC: The World Bank. Pp 173-197.

ABS, Algemeen Bureau voor de Statistiek. 2007. Demografische Data. Paramaribo: Algemeen Bureau voor de Statistiek.

Adger, W.N., J. Paavola, S. Huq and M.J. Mace (eds.). 2006. Fairness in adaptation to climate change. Cambridge, MA: MIT Press.

Allison, M. A., M.T. Lee, A.S. Ogston and R.C. Aller. 2000. Origin of Amazon mudbanks along the northeastern coast of South America. Marine Geology 163: 241-256.

Alongi, D. 2008. Mangrove forests: resilience, protection from tsunamis, and responses to global climate change. Estuarine, Coastal and Shelf Science 76: 1-13.

Arkema, K. K., G. Guannel, G. Verutes, S.A. Wood, A. Guerry, M. Ruckelshaus, P. Kareiva, M. Lacayo, and J.M. Silver. 2013. Coastal habitats shield people and property from sea-level rise and storms. Nature Climate Change 3: 913-918. $\underline{\mathrm{draft}}$

Augustinus, P.G.E.F. 1978. The changing shoreline of Suriname (South America). Utrecht: University of Utrecht.

Augustinus, P.G.E.F. 1980. Actual development of the chenier coast of Suriname (South America). Sedimentary Geology 26: 91-113.

Augustinus, P.G.E.F. 2004. The influence of the trade winds on the coastal development of the Guianas at various scale levels: a synthesis. Marine Geology 208: 145-151.

Augustinus, P.G.E.F. and P. Teunissen. 2004. Morfologische aspecten en natuurlijke kustbescherming. Paramaribo: Sunecon Suriname Engineering Consultants.

Barbier, E., S. Hacker, C. Kennedy, E. Koch, A. Stier and B. Silliman. 2011. The value of estuarine and coastal ecosystem services. Ecological Monographs 81(2): 169-193.

BASC, Board of Atmospheric Sciences and Climate. 2010. Advancing the science of climate change. Washington, DC: The National Academies Press. 
Batterbury, S., T. Forsyth and K. Thomson. 1997. Environmental transformations in developing countries: hybrid research and democratic policy. The Geographical Journal 163(2): 126-132.

Berrenstein, H. 2010. Stress factors of the mangrove ecosystem of Coronie. Academic Journal of Suriname 1: 85-91.

Capricorn Projekt. 2009. An inventory and analysis of the type of support for the fish smoking industry in Suriname. A report for the Ministry of Agriculture, Livestock and Fisheries. Unpublished manuscript, Paramaribo.

Castree, N. and B. Braun (eds.). 2001. Social nature: theory, practice, and politics. Malden, MA: Blackwell Publishing.

Cook, B. 2010. Flood knowledge and management in Bangladesh: increasing diversity, complexity and uncertainty. Geography Compass 4(7): 750-767.

Cook, B. and S. Lane. 2010. Communities of knowledge: science and flood management in Bangladesh. Environmental Hazards 9: 8-25.

Dasgupta, S., B. Laplante, C. Meisner, D. Wheeler and J. Yan. 2007. The impact of sea level rise on developing countries: a comparative analysis. Washington DC: The World Bank.

Delta Commissie. 2008. Working together with water: findings of the Deltacommissie. Heerhugowaard, The Netherlands.

Donato, D., J.B. Kauffman, D. Murdiyarso, S. Kurnianto, M. Stidham and M. Kanninen. 2011. Mangroves among the most carbon-rich forests in the tropics. [Letter]. Nature Geoscience 4(4): 1-5.

Escobar, A. 1996. Constructing nature: elements for a poststructural political ecology. In R. Peet and M.J. Watts (eds.) Liberation ecologies: environment, development and social movements. London: Routledge.

Fairhead, J. and M. Leach. 1996. Misreading the African landscape. Cambridge: Cambridge University Press.

Forsyth, T.J. 2003. Critical political ecology: the politics of environmental science. London: Routledge

Forsyth, T.J. 2011. Politicizing environmental explanation: what can political ecology learn from sociology and philosophy of science? In M.J. Goldman, P. Nadasdy and M.D. Turner (eds.) Knowing nature: conversations at the intersection of political ecology and science studies. Chicago: University of Chicago Press.

Forsyth, T.J. and A. Walker. 2008. Forest guardians, forest destroyers: the politics of environmental knowledge in Northern Thailand. Seattle: University of Washington Press.

Foucault, M. 1994. The subject of power (J.D. Faubion, Trans.). New York: The New Press.

Gatriot, N., E.J. Anthony, A. Gardel, C. Gaucherel, C. Proisy and J.T. Wells. 2008. Significant contribution of the 18.6 year tidal cycle to regional coastal changes. Nature Geoscience 1: 169-172.

Gray, S. T., L.J. Graumlich, J.L. Betancourt and G.T. Pederson. 2004. A tree-ring based reconstruction of the Atlantic Multidecadal Oscillation since 1567 A.D. Geophysical Research Letters 31: 4.

Hannah, L. 2010. Climate change biology. Watham, MA: Academic Press.

Hogarth, P. 2007. The biology of mangroves and seagrasses. Oxford: Oxford university Press.

IaDB, Inter-American Development Bank. 2007. Integrated Coastal Zone Management Plan (SU-T1035): Plan of Operations, Retrieved December 12, 2011, from http://www.iadb.org/

IPCC. 1995. Contributions of Working Group I to the Second Assessment Report of the Intergovernmental Panel on Climate Change. Cambridge: Cambridge University Press.

IPCC. 2001. Contribution of Working Group I to the Third Assessment Report of the Intergovernmental Panel on Climate Change. Cambridge: Cambridge University Press.

IPCC. 2007. Contribution of Working Group I to the Fourth Assessment Report of the Intergovernmental Panel on Climate Change. Cambridge: Cambridge University Press.

IPCC. 2012. Managing the risks of extreme events and disasters to advance climate change adaptation. A Special Report of Working Groups I and II of the Intergovernmental Panel on Climate Change. Cambridge: Cambridge University Press. 
IPCC. 2014. Contribution of Working Group I to the Fifth Assessment Report of the Intergovernmental Panel on Climate Change. Cambridge: Cambridge University Press.

Kerr, R.A. 2000. A North Atlantic pacemaker for the centuries. Science 288: 1984-1985.

McGranahan, G., D. Balk and B. Anderson. 2007. The rising tide: assessing the risks of climate change and human settlements in low elevation coastal zones. Environment and Urbanization 19(1): 17-37.

McLeod, E. and R. Salm. 2006. Managing mangroves for resilience to climate change. Gland, Switzerland: IUCN.

Mearns, R. and A. Norton (eds.). 2010. Social dimensions of climate change: : equity and vulnerability in a warming world. Washington, DC: The World Bank.

Mercer, J., I. Kelman, L. Taranis and S. Suchet-Pearson. 2010. Framework for integrating indigenous and scientific knowledge for disaster risk reduction. Disasters 34(1): 214-239.

Nicholls, R. J., P.P Wong, V. Burkett, J. Codignotto, J. Hay and R. McClean. 2007. Coastal systems and lowlying areas. In M.L. Parry, O.F. Canziani, J.P. Palutikof, P.J.v.d.Linden and C.E. Hansen (eds.) Climate change 2007: impacts, adaptation and vulnerability. Contribution of Working Group II to the Fourth Assessment Report of the Intergovernmental Panel on Climate Change. Cambridge, UK: Cambridge University Press. Pp 44.

Noordam, D. 2007. Geomorphology and soils. Unpublished manuscript, Paramaribo.

OECD, Organization for Economic Cooperation and Development. [accessed September 2013] www.oecd.org/dac/stats/rioconventions

Paavola, J. and W.N. Adger. 2002. Justice and adaptation to climate change. Tyndall Centre for Climate Change Research, Working Paper No. 23.

Parkinson, R. W., R.D. DeLaune and J.R. White. 1994. Holocene sea-level rise and the fate of mangrove forests within the wider Caribbean region. Journal of Coastal Research 10(4): 1077-1086.

Pelling, M. 2011. Adaptation to climate change: from resilience to transformation. London: Routledge.

Ribot, J. 2010. Vulnerability does not fall from the sky: toward multiscale, pro-poor climate policy. In R. Mearns and A. Norton (eds.) Social dimensions of climate change: equity and vulnerability in a warming world. Washington D.C.: The World Bank. draft

Schalkwijk, J. M. 2009. Ontwikkeling als blijvende uitdaging. Paramaribo: Drukkerij Paramaribo.

Spaans, A.L. 2003. Coastal birds of Suriname - kust vogels van Suriname. Paramaribo: Foundation for Nature in Suriname.

Van der Veen, F., D. ter Steege and C. van Binnendijk (eds.). 2010. Dromers, doemdenkers en doorzetters: verhalen van mensen en gebouwen in Coronie. Amsterdam: KIT Publishers.

Walker, P. 2005. Political ecology: where is the ecology? Progress in Human Geography 29(1): 73-82. Reprinted as Walker, P. 2011. Ecologia política: onde está a ecologia? Desenvolvimento e Meio Ambiente 23 (jan./jun): 83-93.

Walker, P. 2006. Political ecology: where is the policy? Progress in Human Geography 30(3): 382-395.

Wekker, J.B.C. 1984. Plaatsbepaling met behulp van historische kaarten. Eldorado 3: 6.

Wells, S., C. Ravilious and E. Corcoran. 2006. In the front line: shoreline protection and other ecosystem services from mangroves and coral reefs. Cambridge, UK: The United Nations Environment Programme World Conservation Monitoring Centre (UNEP-WCMC).

World Bank. 2010. Economics of adaptation to climate change: synthesis report. Washington, DC: The World Bank. 